\title{
LA MUJER ES EL MENSAJE. LOS COROS Y DANZAS DE SECCIÓN FEMENINA EN HISPANOAMÉRICA
}

PILAR AMADOR CARRETERO

Universidad Carlos III de Madrid

\section{LA FUNCIÓN SOCIALIZADORA DEL ESTADO: LA SECCIÓN FEMENINA DE FALANGE ESPAÑOLA}

A los ciudadanos se les puede dominar por la coacción, pero también se les puede conquistar con la convicción. Así, cualquier sistema político ejerce una acción socializadora a través de los departamentos e instituciones dedicados a esta actividad, haciendo que los ciudadanos se integren en la ideología oficial y la adopten como suya. Esta acción puede asumir múltiples y variadas formas ${ }^{1}$.

En los Estado totalitarios, esa acción socializadora se completa con la propaganda. Para que la propaganda totalitaria sea eficaz es necesario que transmita un contenido que satisfaga alguna de las expectativas o necesidades de los ciudadanos. En este caso, el argumento de la propaganda se basa en fórmulas capaces de encender el ánimo y ejercer de estimulante emocional, provocando un deseo y una acción en el receptor. La explicación fundamental de este hecho es que los regímenes totalitarios consideran que se puede manejar más fácilmente a las masas si se les suministran consignas adaptadas al modo sentimental y pasional de su temperamento. En otras palabras, contemplan que lo más apto para el manejo de las masas son los sentimientos extremos de adoración y de odio, de fobias y filias. Para esta labor propagandística se requieren individuos convencidos, que adopten una postura firme y decidida de adhesión ciega, sólo equiparable con la fe religiosa. Estos propagandistas, adeptos al sistema político

1. Para ello utiliza diferentes estrategias que sirven, bien para reafirmar los valores, normas y modelos culturales vigentes, o bien para provocar acciones sociales de rechazo hacia lo que se desea excluir. En el primer caso, la socialización produce la realidad de que se trate; en el segundo la reproduce y perpetúa, contribuyendo al mantenimiento de unas actitudes, normas y comportamientos determinados. 
de que se trate, se convierten en un elemento animador y en mensajeros de una nueva realidad y futuro grandioso.

En la tarea de socializar y adoctrinar a toda de la sociedad, el Estado despliega el conjunto de sus aparatos ideológicos. Es decir, la empresa de transmitir y consolidar la ideología se lleva a cabo por una extensa red de agentes transmisores pensados para esta misión o por agentes que podríamos llamar accidentales que tienen un cometido distinto pero que luego, de hecho, también constituyen agencias transmisoras. Sin embargo, no vamos a entrar aquí en un minucioso y detallado recuento de las estrategias de esta tarea, sólo recordaremos que a través de ese proceso el Estado esparce la idea de bondad y legitimidad de los valores y estructuras sobre las que se basa ${ }^{2}$.

La consecuencia de la socialización es la mentalidad. Es decir, el conjunto de actitudes, reacciones, formas de pensar y entender la realidad; lo que conforma el comportamiento cotidiano.

Llevando estas afirmaciones a la época de Franco es un hecho comprobado que los contenidos ideológicos del régimen sirvieron para legitimarlo y que se articularon y divulgaron a través de un aparato propagandístico que incluía el control de los medios de masas, del sistema educativo y del púlpito. Asimismo, la utilización en este adoctrinamiento de consignas y resortes emotivos puede constatarse especialmente durante el período que nos ocupa ${ }^{3}$. Por ejemplo, después de la Segunda Guerra Mundial, cuando se percibe el peligro de que la oposición y las potencias internacionales puedan reemplazar al régimen por otro liberal que cubriera los requisitos de una democracia formal, la prensa, la radio, la religión, la educación y la cultura se reúnen en una sola voz, intensificando los mensajes de apoyo al régimen y al Caudillo ${ }^{4}$.

La definición ideológica del régimen franquista no puede separarse del decreto de Unificación que creó Falange Española Tradicionalista y de las JONS, asumiendo como bagaje doctrinal e ideológico 26 de los 27 puntos programáticos falangistas. Otro momento crucial es la superposición del Caudillo, cabeza visible del Estado, con la figura de Jefe Nacional de Falange Española, el 31 de julio de $1939^{5}$. Ambos decretos justifican la doble dependencia de la Sección Femenina a los principios falangistas de este partido único y a Franco como Jefe

2. Atthusser, L.: «Ideología y aparatos ideológicos del Estado», en Escritos, Barcelona, Laia, 1974, p. 126; Reich, W.: Psicología de las masas del fascismo, Madrid, Ayuso, 1972, pp. 132-133.

3. RAmírez, Manuel: España, 1939-1975. Régimen político e ideología, Madrid, Guadarrama, 1978, p. 30.

4. Recordemos también la movilización de la plaza de Oriente el 9 de diciembre de 1946, el Referéndum sobre la ley de Sucesión y las consignas del «sí» a Franco y, en fin, la visita a España, en 1947, de Eva Duarte de Perón. Todas ellas manifestaciones multitudinarias que serán justificadas por la propaganda política como «reacción de los españoles ante el aislamiento internacional». Además, durante la campaña del Referéndum, los aparatos de propaganda del régimen, junto a la exaltación de los logros conseguidos gracias a la Guerra Civil, desarrollaron lemas como: «Franco o el Caos", "Franco o el Comunismo", etc . Ver Tuñón De Lara, M. y Biescas, J.A.: Historia de España Labor. Vol X: España bajo la dictadura franquista, Barcelona, Labor, 1980, p. 251.

5. «Supremo Caudillo del Movimiento, personificación de todos los valores y todos los honores del mismo...». Art. 47 de los Estatutos de Falange Española Tradicionalista y de las Jons, Decreto, 31 de julio de 1939. 
Nacional, convirtiéndose en su instrumento y en uno de sus baluartes claves más interesantes.

En este sentido, no cabe duda de la sumisión de las mujeres de la Sección Femenina al Caudillo. De ello hacen manifestación expresa en la concentración de las camaradas de todas las provincias en Medina del Campo en mayo de 1939, con motivo del acto de homenaje al Caudillo y al Ejército después de

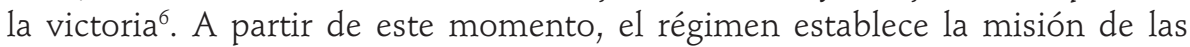
mujeres falangistas dentro del Movimiento y las convierte, como se refleja en las palabras de réplica del Jefe Nacional al discurso de Pilar Primo de Rivera, en "modelo»y en "norma» asignándoles la tarea de formar y promocionar a las otras mujeres basándose en los valores del partido único ${ }^{7}$. Las mujeres de la Sección Femenina se convierten así en portadoras del «espíritu nacional», en fundadoras, reformadoras y apóstoles del nuevo régimen, configurando una "minoría selecta» que sostiene y defiende el caudillaje a la vez que contrae el compromiso ineludible de revelar a las mujeres españolas su destino ${ }^{8}$.

\section{EL MEDIO: LOS COROS Y DANZAS}

En 1942 la revista Consigna publicó un suplemento en el que se explicaba que, oficialmente, la Sección Femenina asumía la tarea de recuperar y conservar el folklore regional. Esta actividad ya existía desde la Guerra Civil, fecha en que se organizaban cursillos para directoras de coros en todas las localidades españolas y, más tarde, la música y los bailes regionales se incluyeron en los programas escolares femeninos en sustitución de los ejercicios gimnásticos fuertes más propios de la enseñanza masculina ${ }^{9}$. Sin embargo, la actividad no

6. Pilar Primo de Rivera tiene palabras de admiración hacia el Generalísimo en sus recuerdos, al que agradece su afecto hacia ella y su ayuda, y muestra su fidelidad y admiración incondicional hacia él: "Y si en esos hombres políticos encontré hacia mí un afecto especial, fue aún más marcado y en mayor grado el que siempre me demostró el Generalísimo. Constantemente nos prestó su ayuda, su colaboración y [...] tenía absoluta confianza y estaba seguro de mi fidelidad [...] Yo, que lo traté a lo largo de los años, puedo decir que siempre vi en él, sobre todo, su amor a España y un inmenso deseo de servirla...». En Primo De Rivera, Pilar: Recuerdos de una vida, Madrid, Nyrsa, 1983, pp. 297-298.

7. "Camaradas de la Falange Femenina, delegada nacional de las Secciones Femeninas y españoles todos que me escucháis: Yo recibo orgulloso el homenaje de la mujer española, por cuanto representa en cariño a nuestros soldados y en honor a nuestros combatientes [...]. Vosotras, mujeres españolas, sois las que habéis dado el ejemplo [....]. No acaba vuestra labor con lo realizado en los frentes [...]. Todavía queda más, os queda la reconquista del hogar. Os queda formar al niño y a la mujer española. Os queda hacer a las mujeres fuertes, sanas e independientes [...]. Tengo fe en vuestra obra. Yo os ayudaré...». En Franco Bahamonde, Francisco: «Discurso a la Sección Femenina en el Acto de Homenaje al Caudillo y al Ejército» (Medina del Campo, 30 de mayo de 1939), en Palabras del Caudillo: 19 abril de 1937 a 7 de diciembre 1942. Madrid, Editora Nacional, 1943, pp. 129-133.

8. "La Falange Femenina tiene por objeto unir a todas la mujeres españolas en el sentimiento ardiente del servicio a la Patria, sobre la base de los principios del Nacionalsindicalismo. La Falange Femenina se extiende a toda las capas de la sociedad». En Enciclopedia Escolar Aguado. Grado Superior Madrid, Aguado, 1943, citado por OTero, Luis: La Sección Femenina, Madrid, EDAF, 1999, p. 16.

9. Circular de 15 de junio de 1942, emitida por la Asesoría de Religión y Moral y firmada por Ramiro López Gallego, Capellán Nacional. 
cobra importancia hasta finales de la década cuando, en las exhibiciones nacionales, se suscitan comentarios elogiosos sobre la misma por parte de algunos intelectuales ${ }^{10}$.

En la nueva andadura de los Coros y Danzas el contexto internacional era poco prometedor para el régimen y el Caudillo. De modo que la Sección Femenina, siguiendo la consigna del informe redactado por Carrero Blanco sobre la supervivencia del régimen ${ }^{11}$, adoptará la fórmula de "orden, unidad y paciencia» mientras dure la amenaza. Bajo ese lema y durante esos años difíciles para Franco, las afiliadas de cada provincia y comarca estuvieron empeñadas en la tarea de recuperar el folklore regional, asimilando fielmente cada gesto, palabra y canción.

La primera exhibición internacional se realiza en 1948. La propaganda oficial declara que el objeto de esta salida es corresponder a la visita que había realizado a nuestro país Eva Duarte de Perón un año antes y expresar la gratitud de España a la Argentina ${ }^{12}$. Este objetivo justificaba ampliamente el viaje internacional ya que la ayuda argentina había sido decisiva no sólo porque este país había defendido a España en la Asamblea General de las Naciones Unidas, sino también, porque, haciendo caso omiso a la resolución final, había enviado su embajador y firmado acuerdos con Franco para la venta de trigo a crédito. El momento era oportuno porque quedaba atrás la amenaza de oposición monárquica, republicana y de izquierda pues la guerra fría abría esperanzas para el franquismo, que ya podía percibir el desinterés de las potencias occidentales en deponer a Franco.

En cualquier caso, el viaje tenía sus riesgos porque no hacía mucho los exiliados españoles, esgrimiendo razones políticas, habían impedido en Buenos Aires un homenaje a Jacinto Benavente y, por tanto, exponer, en ese contexto, a las

10. La actividad entraba dentro de la Regiduría de Cultura (Departamento de Música) y tenía la finalidad de promover y estimular la difusión de la cultura musical en todo el ámbito nacional. En las actuaciones de los Coros y Danzas participaron y se movilizaron más de 75.000 componentes que llevaron las canciones y las danzas españolas prácticamente por todo el mundo. Vier Informe sobre la Sección Femenina, elevado al Consejo Nacional del Movimiento (12 de febrero de 1969), en Primo de Rivera, Pilar: Op. cit, pp. 397-414. Relacionado con el tema de los Coros y Danzas puede consultarse también la publicación reciente de CASERO, Estrella: La España que bailó con Franco. Coros y Danzas de la Sección Femenina, Madrid, Nuevos Estudios S.L., 2000.

11. Carrero Blanco redactó un informe en el que se exponían los logros de Franco y del régimen. En él subrayaba que España era un país independiente, políticamente libre, vigoroso y en ascenso y que era bastante improbable que Gran Bretaña y Francia se arriesgaran, mediante el apoyo a los republicanos exiliados, a favorecer el comunismo en España después de la declaración de Potsdam. La única fórmula posible para los españoles era seguir fielmente los principios que el orden, la unidad y la paciencia marcaban, combinados con una acción policial eficaz que castigara, sin temor a las críticas de fuera, cualquier acto de subversión. Ver López Rodó, Laureano: La larga marcha hacia la Monarquía, Barcelona, Noguer, 1977, pp. 57-59.

12. SuÁrez Fernández, Luis: Crónica de la Sección Femenina y su tiempo, Madrid, Nueva Andadura, 1993, p. 216. 
jóvenes de los Coros y Danzas a una recepción adversa podía provocar efectos contrarios a los esperados.

La decisión se toma finalmente en el Castillo de la Mota, durante un encuentro al que asistieron el embajador argentino, Pedro Radio, y Pilar Primo de Rivera. En un barco de carga y pasaje perteneciente a la Naviera Aznar, el "Monte Albertia", viajará esta primera expedición bajo la dirección de Eulalia Ridruejo y María Josefa Hernández Sampelayo ${ }^{13}$. Al llegar a Mar del Plata, el general Perón, su esposa y algunas representaciones de la colonia española le dan la bienvenida.

Cuando terminan las primeras actuaciones, ya se advierte que lo que había comenzado en tono oficial se había transformado en algo nuevo para los anales de la propaganda política del régimen, porque las canciones y los bailes de la propia tierra, transmitidos por esta expedición de jóvenes mujeres, resultaban ser resorte emotivo y profundo capaz de hacer sentir a los emigrantes la nostalgia de la Patria y calmar las irritaciones y el rencor de los exiliados políticos.

A finales de julio, las expedicionarias estaban de regreso en sus casas y la Sección Femenina les concede la «Y» colectiva, pidiendo condecoraciones singulares paras las dirigentes responsables del éxito. El periódico Arriba publicó el mensaje de Pilar Primo de Rivera en el que agradecía y explicaba la expedición y en el que puede apreciarse lo que serán los rasgos característicos del lanzamiento propagandístico de estos grupos ${ }^{14}$.

13. Esta primera expedición estaba compuesta por 150 personas, mujeres en su mayoría, ya que, inicialmente, los grupos mixtos de baile no estaban permitidos: «[...] es norma indeclinable del Frente de Juventudes que por ningún pretexto haya coeducación, es manifiesto que no cabe admitir bailes regionales mixtos, y en alguno en que era de rigor tomasen parte varones, la parte del varón la ejercían también las mujeres. Por tanto, la norma es clara: no pudiendo haber coeducación y tratándose de enseñanzas, no es posible acceder a que los bailes sean mixtos, de chicas y chicos....». En Circular de 15 de junio de 1942, emitida por la Asesoría de Religión y Moral y firmada por Ramiro López Gallego, Capellán Nacional. Respecto a la expedición, los datos vertidos por Estrella Casero coinciden con los aportados por Luis Suárez en las obras citadas.

14. «Parece que fue ayer cuando os despedíamos en Cádiz, con la incertidumbre todavía de qué resultado tendría vuestra expedición. Había muchas probabilidades de éxito: primero vosotras, después la misión cultural que llevabais y la nación a donde ibais; pero, sin embargo, una interrogante pendía en el ánimo de todos, y con ese riesgo acometimos la empresa, porque bien sabemos en la Falange que el que no se arriesga no pasa la mar, y que el que no se expone a perder nunca ganará nada. Y, además, porque la verdad es que en la Falange nos gustan las cosas un poco arriesgadas; les encontramos más gracia. Pedimos la bendición de Dios, y zarpó el «Monte Albertia» entre los sones del Cara al Sol ahora hace poco más de tres meses. Al cabo de los cuales no podéis ni imaginaros, camaradas realizadoras de esta prodigiosa empresa, el servicio que habéis prestado a España. Bien es verdad que hemos recibido muchas ayudas: la primera y más importante, la de Dios; la de la nación adonde ibais, el embajador español, promotor de la idea con la Sección Femenina y constante aliento y apoyo de nuestros Grupos en la Argentina -se trataba de José María de Areilza-; las facilidades económicas y la ayuda moral otorgadas por los Ministros españoles y por la Compañía naviera; pero así y todo hubiera fracasado la empresa si vosotras no hubierais sido vosotras; es decir que, como siempre, y según decía José Antonio, «el hombre es el sistema». [...] «Porque si importante es la labor cultural que allí habéis realizado; si por vuestra maravillosa gracia han sentido la nostalgia de la Patria lejana 
A partir de ese momento, los grupos de Coros y Danzas de la Sección Femenina recorrerían el mundo en misión cultural y política, como propagandistas adeptas al régimen, elemento animador y vivificador, mensaje emotivo de la nueva realidad y el nuevo futuro de España.

\section{EL CINE Y LA HISTORIA: EL FILME RONDA ESPAÑOLA}

Desde la perspectiva defendida por Marc Ferro y otros investigadores abordamos la utilización del filme entendiéndolo como fuente para la historia, producto cultural de una sociedad determinada ${ }^{15}$. Desde estos planteamientos, se considera que el cine contribuye al mantenimiento de la sociedad y de la ideología que la sustenta.

Desde esta perspectiva, ya defendida en otros trabajos, consideramos que la imagen cinematográfica no sólo tiene una significación y un propósito que le es conferido de acuerdo a los esquemas mentales de su creador, sino también que éste no puede evitar la realidad del momento en que esa obra se produce, porque también él participa de los códigos y mensajes de esa realidad y los entreteje y refleja -consciente o inconscientemente- en el espacio ficticio del filme.

En efecto, el cine refleja lo que ha quedado sedimentado y cristalizado de la ideología en la sociedad del momento. Es decir, los comportamientos de la mentalidad vigente. De ahí que la consideración de la forma de pensar, de las actitudes y reacciones que integran la mentalidad que se reflejan en el filme

tantos españoles ausentes de ella; si los argentinos han vuelto a enorgullecerse con el origen de su sangre española, una de las cosas más importantes que allí habéis conseguido es el asombro de todos ante el comportamiento de cada una de vosotras; es la admiración unánime ante la nueva generación española, llena de espontaneidad, de gracia y de alegría, pero tan profunda y tan seria en lo fundamental. Y a ese fenómeno, que tanto les extraña, nosotros encontramos una explicación clarísima: 'el modo de ser que es la Falange', vivido día tras día en nuestras Secciones Femeninas y que ha hecho posible que con este viaje hayáis sabido ganar para España prestigio y fama, cumpliendo así nuestro destino en lo universal. Porque España, como afirma José Antonio, 'no es un territorio ni un agregado de hombres y mujeres; España es ante todo una unidad de destino, una realidad histórica, una entidad verdadera en sí misma, que supo cumplir y aún tendrá que cumplir misiones universales'. Porque no sólo a la Argentina, sino también al Brasil y a Portugal, habéis llegado con todos los valores de la tradición hispánica, usando de la cordial acogida que los Gobiernos de ambos países han otorgado a nuestros Coros y Danzas.» [...] «Después de lo que habéis hecho, sólo nos queda dar gracias a Dios, ofrecer al Caudillo los laureles recogidos y demostraros nuestra conformidad con vuestro comportamiento concediéndoos a todas las "Y» colectiva, singladura y emblema de nuestra Reina Isabel. Mejor premio no puede tener esta empresa». En "Informe sobre la Sección Femenina», Arriba, 8 de agosto de 1948, citado por Suarez Fernández, Luis: Op. cit., pp. 218-219.

15. Ver Ferro, Marc: Analyse de film et analyse de sociétés, París, Hachette, 1975; Sorlin, P.: Sociologie du Cinema: ouverture pour l'Histoire de demain, París, Aubier-Montaigne, 1977; PAz, M.A. y MonTero, J. (edits.): Historia y Cine (Realidad, ficción y propaganda), Madrid, Editorial Complutense, 1995; Rosenstone, Robert: El pasado en imágenes, Barcelona, Ariel, 1997. Asimismo, José María Caparrós ha editado un interesante artículo en el que hace una síntesis de las publicaciones a que ha dado lugar la relación entre el Cine y la Historia en el contexto español: CAPARRós LerA, J.M.: «Relaciones Historia-Cine en el contexto español» en A. Yralola (comp.): Historia Contemporánea de España y Cine, Madrid, Universidad Autónoma de Madrid, 1997, pp. 11-26. 
nos permita detectar la ideología que ha ido calando en la sociedad. Para el historiador analista que sabe «ver» en ese texto, el mismo se presenta como un conjunto de mensajes, como un contenido que ha contribuido al mantenimiento de esa determinada sociedad e ideología.

Esta afirmación puede comprobarse especialmente durante la época de Franco, donde todos los organismos e instituciones oficiales y los medios de comunicación de masas constituyeron una orquesta destinada a propagar los dogmas doctrinales y las consignas políticas del régimen ${ }^{16}$.

Así, para este trabajo, nos hemos fijado en la película Ronda Española en la que se recoge y representa la actividad de los Coros y Danzas de la Sección Femenina en sus viajes por Hispanoamérica. Este documento es un elemento más para acercarnos a la realidad de las mujeres falangistas y a los principios e intencionalidades de su mensaje. En otras palabras, nos sirve para reconstruir la memoria histórica. En efecto, a través del análisis de este filme, comprobaremos que la actividad de los Coros y Danzas, aparentemente apolítica, fue utilizada con la intencionalidad de atraer e integrar a los ciudadanos $y$, que, por tanto, las mujeres que participaron en ella fueron utilizadas por el régimen de Franco como mensaje ideológico ${ }^{17}$.

\subsection{El director y el guión}

Según Luis Suárez, la idea de convertir en película el viaje de los Coros y Danzas por Hispanoamérica surgió en 1949, en Francia, cuando W. de Basili, responsable del ballet ruso, sugería a Elisa de Lara la conveniencia de hacer una película con intriga romántica que sirviese como vehículo para despertar el interés de los espectadores por el folklore españo ${ }^{18}$. La idea se materializa más tarde, entre enero y abril de 1950, fecha en que se elige para la película el título de Ronda Española, y la Sección Femenina firma el contrato para su realización con los Estudios Chamartín.

Rafael García Serrano (Pamplona, 1917-Madrid, 1988) y José María Sánchez Silva (Madrid, 1911-) realizaron el guión de la película. Ambos pueden considerarse escritores y guionistas afectos al régimen. Rafael García Serrano era militante falangista desde antes y durante la Guerra Civil y sus escritos se estiman abiertamente acordes con los valores ideológicos del momento. Además, García Serrano acompañó a esta primera expedición como cronista oficial, escribiendo las anécdotas y observaciones del viaje, crónicas que posteriormente recopiló y publicó en el libro Bailando hasta la Cruz del Sur ${ }^{19}$.

16. Ver los diferentes trabajos publicados en CAMARero, Gloria (edit.): La mirada que habla: Cine e ideologías, Madrid, Akal, 2002.

17. Como se recordará, en el contexto del régimen de Franco esta actividad folklórica de la Sección Femenina ha sido poco considerada desde el punto de vista político. Sin embargo, en este trabajo veremos que, dejando al margen la aportación de estos grupos al folklore español, los mismos tuvieron gran importancia como mecanismo de transmisión ideológica.

18. SuÁrez Fernández, Luis: Op. cit., p. 227.

19. Carcia Serrano, Rafael: Bailando hasta la Cruz del Sur, Madrid, Gráficas Cies, 1954. Reeditado en Barcelona, Planeta, 1984. 
José María Sánchez Silva, destacado también por la actividad de guionista, había manifestado esta ideología afín a través de trabajos en los que se aprecia una marcada tendencia religiosa y una encendida defensa de la contienda y del régimen. Para el argumento del filme, estos guionistas toman algunas de las actuaciones americanas de los Coros y Danzas (especialmente las de Argentina, Colombia y Panamá), y trenzan con ellas una historia romántica de final feliz.

Ladislao Vajda dirigió la película. Se trata de un director bastante peculiar ya que era de origen húngaro pero nacionalizado español (Budapest 1906-Barcelona, 1965). Hijo del dramaturgo del mismo nombre, se había iniciado en la dirección cinematográfica en Gran Bretaña, Hungría, Francia e Italia para llegar a España en 1942. En el contexto de la época, si bien aportó al cine español un aspecto más europeo y cosmopolita, se trata de un director apreciado particularmente por el régimen, con el que mantuvo cierta identidad ideológica que se constata en comedias y algunas incursiones dramáticas ${ }^{20}$. Independientemente

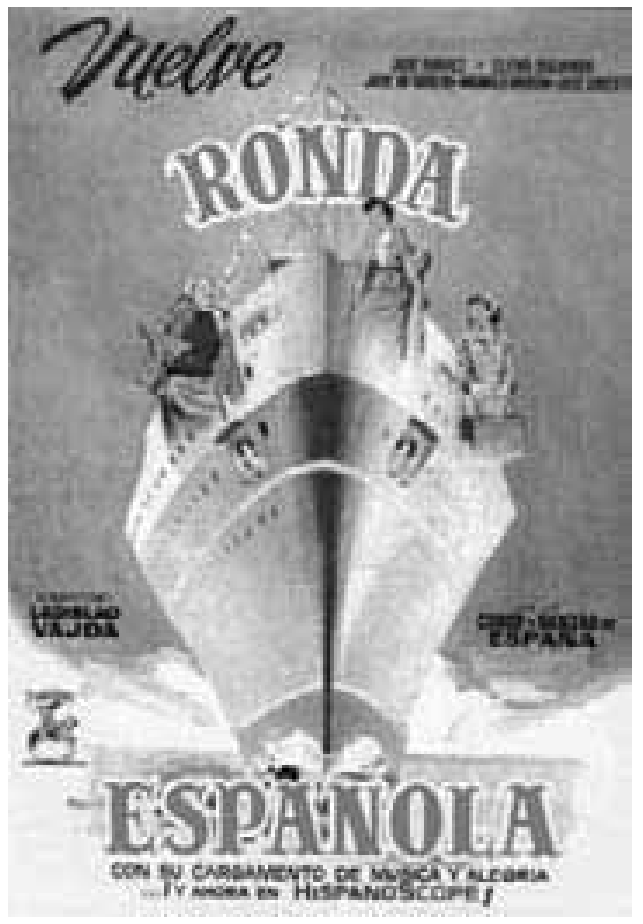
de su integración en la España del momento, este director era proclive a las películas de ambiente español, cosa que había manifestado en otros momentos, indicando el éxito taquillero que los temas vernáculos tenían en el mercado nacional y extranjero. Sin embargo, tampoco se nos escapa el hecho de que en el contexto del cine de esta época el sistema de licencias de importación, de subvenciones y permisos de doblaje hizo que se produjeran películas con la única finalidad de conseguir estas licencias y permisos, cuestión con la que muy bien podría relacionarse este filme ${ }^{21}$.

La película contó con intérpretes conocidos como José Suárez, Elena Salvador, José Isbert y Manolo Morán y con la actuación de más de 500 integrantes de los

20. Recientemente se ha publicado su biografía con motivo del homenaje a este director en el Festival de Cine de Valladolid el año 1997. Ver Luinás, Francisco: Ladislao Vajda: el húngaro errante, Valladolid, Seminci, 1997.

21. En una entrevista de Fernando Vizcaíno Casas para la revista Triunfo, Ladislao Vajda se manifiesta en este sentido, afirmando que las películas españolas que mayores éxitos logran son las de temas españoles. En cuanto a la obtención de licencias y permisos, ver Torres, A.: Diccionario Espasa. Cine Español, Madrid, Espasa-Calpe, 1996, pp. 22 y 23. 
Coros y Danzas que actuaron sin percibir remuneración alguna. En el contrato se especificaba que la Sección Femenina percibiría el 15\% de los beneficios y unas 200.000 pesetas de la subvención estatal si la película era calificada de "mérito extraordinario», además de comprometerse a que los Coros y Danzas no aparecieran en ningún otro filme antes de 1956.

Ronda Española fue estrenada el 8 de noviembre de 1951 con gran éxito de la crítica y el público ${ }^{22}$. La coyuntura era la más oportuna. Franco había cambiado en el mes de julio a la mayoría de los miembros del Gobierno y la situación interna era relativamente segura, después de superar la sacudida de Barcelona y las huelgas en Madrid y Bilbao. En el plano de las relaciones internacionales, el Estado español se afianzaba ya en el mundo diplomático occidental, ahora inmerso en las tensiones de la guerra fría ${ }^{23}$.

\subsection{El contenido del discurso. El mensaje}

Al abordar el análisis del texto fílmico, además de todo lo anteriormente expuesto, hay que considerar que, en la Teoría de la Comunicación, el mensaje se elabora y contiene los valores de la ideología vigente. Por tanto, se llega al hecho de que el filme Ronda Española no sólo recoge de forma coincidente las posiciones ideológicas y culturales de los autores sino que también está en consonancia con la ideología de esta época histórica y los planteamientos del cine nacional en el que este tipo de producciones folklóricas obtenía grandes éxitos comerciales $^{24}$.

Desde estos planteamientos, considerar que las mujeres que intervinieron en los Coros y Danzas en estos viajes internacionales son parte de la ideología del régimen supone también considerarlas como mensaje ${ }^{25}$. En efecto, tomando ya el filme como materia de estudio, observamos que, respecto a las mujeres de los Coros y Danzas, la imagen cinematográfica nos propone un mensaje en dos sentidos: mensaje de las mujeres en sí mismas; mensaje de la actividad que se les encomienda. Ambos están íntimamente imbricados en una relación imposible de separar.

En el mensaje en sí misma (mujer-mensaje) se propone a las mujeres como "modelo", cosa que se descubre en el atractivo femenino, en la forma de vivir, moverse, pensar y creer. Modelo que es aplicable también a las restantes mujeres españolas.

22. SuÁRez Fernández, Luis: Op. cit., pp. 227-228.

23. Tuñón de Lara, M.: «El poder y la oposición» en M. Tuñón de Lara y J. A. Biescas: Op. cit., p. 261.

24. CAmporessi, V.: Para grandes y chicos. Un cine para los españoles (1940-1990), Madrid, Turfan, 1993, p. 34.

25. Resulta evidente que el emisor, receptor y mensaje deben situarse en el mismo contexto socio cultural (cúmulo de conocimientos que ambos tienen por el simple hecho de vivir en cierta sociedad) a fin de que la comunicación sea efectiva. Esto será una preocupación permanente del comunicador si desea ser entendido. Ver VIDALEs, Ismael: Teoría de la comunicación, México, Limusa, 1985, p. 22. 
Un factor decisivo que configura y explica este modelo es la insistencia en definir a estas mujeres como "no profesionales» y como "hijas de familia»" Con la expresión "no profesional» aplicada a las componentes del grupo se rechaza su vinculación con las mujeres del teatro (bailarinas, actrices, cupletistas, tonadilleras) a las que se adscribía comúnmente un carácter ligero y fácil y se subraya el carácter de «hijas de familias honradas». La familia, en la España de Franco, es la cuna de la sociedad civil y la base de todo el edificio social, portadora de los valores eternos del régimen. Por ello, con esta expresión se quiere significar que son mujeres que han recibido una enseñanza cívica, moral, religiosa y patriótica que las capacita para situarse en la vida.

Pero ¿en qué consiste esta educación? ¿Cuáles son las cualidades y virtudes que las adornan, a través de las que se define ese modelo?27

De todas las cualidades, la primera que puede percibirse en el filme es el orden. Esta virtud se refleja tanto en la colocación de las cosas (cada cosa en

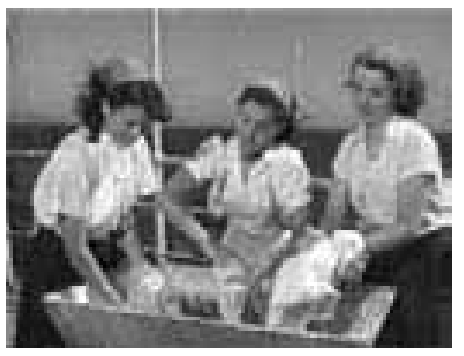

Mujeres lavando su sitio y un sitio para cada cosa) como en el aspecto personal (bien peinadas, uniformes impecables, sin manchas ni arrugas). La tarea doméstica de lavar y planchar la propia ropa se repite en varios momentos del filme y también al final de la travesía cuando las chicas sacan los trajes y calzado que van a utilizar en las exhibiciones y se dedican a revisar y poner a punto todo el equipo (plancha, cosido de botones, limpieza de zapatos, etc. $)^{28}$.

Partes del orden son la cortesía, la compostura y el respeto que es también acatamiento. Una buena hija de familia es, ante todo, obediente, sometiendo su voluntad a los superiores (Dios, autoridades, padres, maestros, etc.). Este acatamiento es percibido en el filme en la inexistencia de conflictos y discrepancias y en el ambiente de armonía que se vive.

26. En varias ocasiones se subraya esta cuestión. Así, en las primeras secuencias del filme, escuchamos la voz del narrador que nos informa de que ha comenzado el viaje: "Conviene que nuestros oyentes sepan que estas chicas han dejado sus trabajos en el campo, en el taller, en la oficina, en la universidad para convertirse en las más extrañas danzarinas del mundo. Bailarán en el Atlántico, Pacífico, Caribe y ninguna de ellas es bailarina». Después de la primera actuación, cuando el barco se dirige a Panamá, el locutor de radio dice en la despedida: «Adiós bellas españolitas, que llevéis todas buen viaje es lo que nosotros deseamos. Piensen que estas muchachas son hijas de familia y no profesionales[...]. Piensen que como estos catorce hay mil grupos en España.»

27. Estas cualidades se constatan en el texto de Werner, Carmen: Convivencia Social (Formación familiar y Social), Madrid, Sección Femenina, 1958, que tuvo varias ediciones, destinadas a las alumnas que asistían a las Escuelas de Hogar y para la asignatura de Convivencia Social de Bachillerato.

28. El orden del barco es el mismo que se exigía en los albergues y escuelas de la Sección Femenina: izaban banderas, rezaban las oraciones y las chicas hacían todas las tareas domésticas (camarotes, servicios de comedor, cuidado y limpieza de los trajes, etc). Ver Primo DE Rivera, Pilar: Op. cit., p. 201. 
Las protagonistas del filme son ejemplo de amabilidad y simpatía. En la ideología del momento, la amabilidad sirve de lazo de unión entre los miembros de la familia y los de la sociedad y es una cualidad que requiere buenos modales porque es la base de la bondad. Todas estas cuestiones pueden advertirse en el trato cotidiano entre las componentes de la expedición. Gracias a la amabilidad y a la simpatía las chicas puede conquistar el aprecio general, cosa que expresa el Capitán al dictar el informe para el diario del viaje ${ }^{29}$.

La alegría es otra cualidad femenina ${ }^{30}$. Para resultar simpáticas y atractivas las componentes del grupo sonríen y se muestran alegres, contentas y satisfechas de lo que tienen y de lo que les rodea. Canciones y bailes son el exponente de esta alegría, de esta satisfacción. Con ello se produce una especie de corriente agradable entre el hacer de los grupos y quien recibe su actuación.

La amistad es un sentimiento con el que se inicia el filme y se mantendrá constante en toda la historia. En Ronda Española, la amistad nace del interés por las penas y alegrías compartidas, lo que se traduce en acciones como escuchar o ayudar de manera leal. Así, al comenzar el filme, Victoria consigue ser admitida en el grupo de San Sebastián gracias a una amiga que escucha sus confidencias y le cede el puesto para que pueda volver a ver a su hermano, exiliado a causa de la Guerra Civil. Más tarde, en la relación entre las chicas durante el viaje, la amistad es un sentimiento que se mantiene constante, aunque la mayor demostración de este sentimiento se expresa en la relación entre Ángeles y Victoria cuando la primera la respalda en la visita a su hermano sin que se entere la Jefe del grupo y cuando presta su ayuda a Pablo en los acontecimientos posteriores. Y, en fin, la amistad lleva a Ángeles a esconder las pastillas del capitán para obligarle a que deje de beber y hacerle un favor ${ }^{31}$.

29. La acción seductora se percibe como un proceso gradual. Así, antes de salir del puerto, los capitanes de los barcos mercantes hablan de la carga que transportan. Esta conversación sirve para presentarnos al capitán del "Monte Albertia», que se siente fastidiado por su carga. Con mal humor informa a sus compañeros de que lleva «120 chicas y va al lastre de todo...». El fastidio reaparece cuando da la orden de inmediata partida con objeto de acelerar la vuelta: "Antes estarán estas señoritas en su casa, que es donde debían estar.» o durante la comida cuando la Jefe del grupo le pregunta si se marea, él contesta: «no me mareo, me marean, que no es lo mismo...» Este constante malhumor terminará en admiración, que expresa al redactar el diario de navegación: «Pese a lo que era de temer, el viaje se desenvuelve sin incidentes. Chicas se comportan de modo encantador...».

30. Estas características pueden encontrarse en innumerables textos editados por la Sección Femenina. Sirva como ejemplo un fragmento de un editorial de la revista Medina, abril de 1943: "Queremos para nuestra juventud una alegría viva, pujante, que esté en sus pechos y que salga en ecos sonoros de voces unidas y acordes[...]. Y la alegría de la Patria está en nuestra juventud [...] dando una misma canción al viento, canción que crece y se extiende y se multiplica en miles de voces y en miles de lugares y es el eco recogido de todo el clamor de la Patria, en recuerdo y en esperanza».

31. Cuando el Capitán se lamenta de la pérdida de sus píldoras la Jefe (que lo sabe todo, que está al tanto de todo) le contesta: «Alguien ha podido tomar las píldoras para hacerle un favor. Buscaré a la chica y la felicitaré por hacer una buena acción». 
Comportarse valerosamente e incluso perder la vida, si el servicio a la Patria lo requiere, es propio de la raza española. Las componentes del grupo, si bien son previsoras y actúan observando las reglas, son capaces de actuar con valor, soportando con paciencia las molestias físicas de los primeros días de navegación, el dolor de la separación de los seres queridos (Pablo y Victoria) y con dignidad o sin miedo la acción de los terroristas.

España y la religión católica son dos conceptos que, como se ha señalado, marchan unidos durante el franquismo. En el discurso oficial, la asistencia divina a España y a los españoles es la base del nacional catolicismo ${ }^{32}$. Gracias a la Providencia, que vela constantemente por los españoles, estos han podido salvarse a lo largo de la historia de los enemigos que los tenían esclavizados
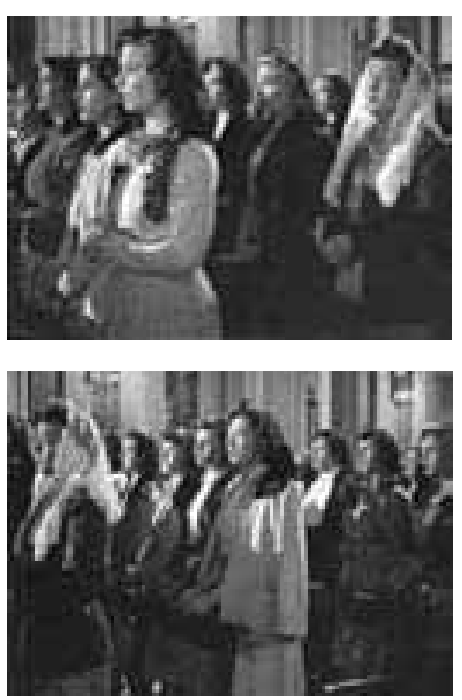

Mujeres con velos en misa y que los llevaban hacia su aniquilamiento. Como contrapartida, el pueblo español se distingue por su fe, devoción y sincero fervor. Estos valores de la religiosidad se constatan en las componentes en distintos momentos de la expedición. Por ejemplo, en las expresiones de agradecimiento o de invocación a Dios o a la Virgen para lograr su ayuda antes de las actuaciones, cuando se enfrentan con los terroristas y en diferentes actos litúrgicos (la misa mayor, cantada del día de Navidad y oraciones de cada día, etc.) ${ }^{33}$.

El perdón y el arrepentimiento, elementos fundamentales del sacramento de la penitencia están presentes. Así, para la oración de la secuencia final, cuando Pablo decide volver a España y regresa al barco, se elige un fragmento del libro de los Salmos que es,

32. José Antonio Primo de Rivera establece como postulado fundamental de su doctrina política un concepto religioso: «el hombre portador de valores eternos». Este postulado tiene una proyección en el sistema político que obliga a éste a proyectar una política en función del destino natural y sobrenatural del hombre. La ley de Principios del Movimiento Nacional (17 de mayo de 1958) reivindica este postulado en el punto II: La Nación española considera como timbre de honor el acatamiento a la Ley de Dios, según la doctrina de la Santa Iglesia Católica, Apostólica y Romana, única verdadera y fe inseparable de la conciencia nacional, que inspira su legislación». Ley de Principios del Movimiento Nacional (17-V-1958) en Leyes Fundamentales del Estado. Colección "Documentos Políticos", Madrid, Ministerio de Información y Turismo, 1966, p. 21. Para el tema del nacional-catolicismo consultar el estudio de Álvarez BoLADo, Alfonso: El experimento del nacional-catolicismo (1939-1975), Madrid, Cuadernos para el Diálogo, 1976.

33. "La religión es la vida humana religada a Dios, es la relación constante y total de la existencia del hombre con el autor de la misma. Por esta razón [...] cada acto humano, ya responda a su dimensión natural o histórica, es, en cierto modo, un acto religioso...». DeleGACión NACionAL de Sección Femenina: Formación Política. Principios del Nacionalsindicaismo, Madrid, Almena, 197 $0,14^{\mathrm{a}}$ ed., pp. 25 y ss. 


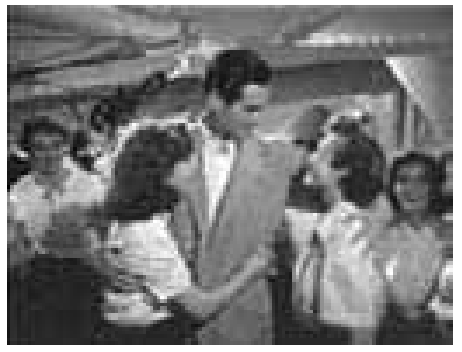

Pablo abraza a Victoria y a Ángeles en realidad, la súplica confiada de un afligido (ese Pablo arrepentido y suplicante que vuelve a casa) con el que se completa la metáfora del «hijo pródigo» que el filme propone como conclusión final ${ }^{34}$.

Las referencias al patriotismo son, si cabe, más evidentes porque, además del amor a la Patria, en ese concepto se integra la tradición, lo popular tal como es y, por tanto, el folklore. De modo que las mismas actuaciones ya son un acto de patriotismo.

Esto se percibe claramente en la secuencia en que la Jefe del grupo se dirige a las muchachas antes de la primera actuación de los Coros y Danzas, en cuyas palabras pueden sintetizarse la mayor parte de las consignas anteriores, tales como «la no profesionalidad de esta actividad», «el patriotismo», etc.: "Advierto a la que no lo sepa que los nervios deben quedarse en el guardarropa. Nadie piense que está en el escenario de un teatro. Esto es la plaza del pueblo de cada una de vosotras. Tenéis que bailar como lo haríais allí. Eso es lo que se os pide. De este modo quienes están ahí fuera se creerán de nuevo en la Patria. Pensad que algunos se alejaron de ella no sólo físicamente sino de una manera más drástica y definitiva. Y pensad que lo que vais a comenzar dentro de un rato es un mensaje. En fin, bailad con toda el alma $»^{35}$.

Otro momento del filme en el que se expresa este sentimiento es en la jota que canta el grupo de Aragón en el bar del Club Español y que es interrumpida por Pablo con una música moderna. El significado de esta interrupción es, en realidad, el rechazo hacia España porque, como hemos señalado, en el discurso de propaganda falangista, el folklore es «lo es-

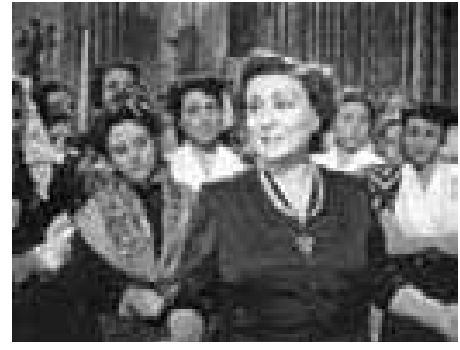

La Jefe se dirige a las chicas

34. El fragmento es: "Tu eres mi amparo y mi refugio, tu verdad me protege como un escudo» . Pero pueden encontrarse también otros textos similares en los que se incluye de alguna forma la primera parte del salmo, dándole un significado más acorde con el momento a la segunda: «Por Tu nombre, dirígeme y guíame, sácame de la red que me han tendido, por que Tú eres mi amparo» o bien «Sé Tú, Señor, la roca de mi refugio, un baluarte donde me salve» .

35. En realidad estas consignas ya están presente el 17 de abril de 1948 en el discurso de despedida de Pilar Primo de Rivera a la expedición: "Tan importante es la misión que lleváis [...] de recuperar para España el interés de los argentinos y de llevar a los españoles que allí viven toda la tradición auténtica de la Patria lejana. Misión en lo Universal; vosotras sabéis que España no se justifica si no cumple una misión en la Historia, si no entra en las empresas del mundo con sentido de universalidad. Pues bien, eso es lo que vais a hacer con vuestros coros y danzas como parte que sois de esa política que dirige el Caudillo.» En Primo de Rivera, Pilar: Op. cit., p. 239. 
pañol» lo que se contrapone a los bailes modernos ${ }^{36}$. Finalmente, ingredientes importantes de este patriotismo son el orgullo y la honra de ser español a los que alude la letra de la jota ${ }^{37}$.

Pablo y sus amigos hacen alusión de forma despectiva y preocupada al patriotismo que pueden despertar en los españoles exiliados estos bailes y canciones ${ }^{38}$. En efecto, el filme permite al espectador comprobar, más tarde, cuando los exiliados van a intentan boicotear la actuación y terminan por unirse al entusiasmo general, cómo se reverdece este sentimiento en los exiliados al ir apareciendo en el escenario los grupos de sus provincias.

El patriotismo sirve también para aludir al concepto falangista de la Patria, entendida no sólo como el lugar donde se ha nacido, la belleza de sus paisajes o la emoción de sus canciones y bailes, sino porque tiene un destino universal que se concreta en la propagación y defensa de unos valores espirituales y culturales $^{39}$. En este sentido, el filme establece una jerarquía entre los españoles del régimen, integrantes conscientes de esa misión y los emigrantes-exiliados que sólo ven superficialmente a España, lo que se expresa en la nostalgia de la parte física y material (territorio, lengua, costumbres, bailes, canciones, etc.) ${ }^{40}$.

El patriotismo, en fin, se contrapone a la traición y sirve en el filme para subrayar el engaño en que están inmersos los exiliados políticos, cosa que Victoria advierte ya en su primera visita a Pablo, después de que le inste a volver a

36. «Nos entusiasma pensar en que sea desterrada de nuestra Patria la música exótica, con todo su acompañamiento de negros y bailarines contorsionistas y descoyuntados espiritual y físicamente». Ver AlCARAZ, Juan de: "El arte musical de la Nueva España», citado por Otero, Luis: Op. cit., p. 214.

37. La letra de la jota dice: «Cuando la Patria me llama para ir a luchar, siento el orgullo y la honra de ser de Aragón/ Cuando la Patria me llama para ir a luchar, siento el orgullo y la honra de ser español./ Cuando la Patria me llama para ir a luchar, llevo en mis labios la jota que tanto yo amé y en mi memoria mi madre, mi gente, el Pilar/ y en mi memoria mi madre, mi gente, el Pilar, siento el orgullo y la honra de ser español».

38. Varios personajes escuchan por radio la noticia de que los Coros y Danzas se dirigen hacia Panamá. Se produce un diálogo entre ellos que sirve para que el espectador conozca a Pablo, hermano de Victoria, y para despertar un sentimiento de rechazo hacia el resto de los que se sospecha una amenaza. Así, después de que Pablo aclare que San Sebastián es la capital de su provincia, se refiere al patriotismo que las muchachas pueden despertar entre los exiliados: «En todo caso se limitarán a despertar con su presencia una nube de patriotismo pero tan inconsistente». A esta afirmación un poco despectiva de Pablo replica el cabecilla con preocupación: «Los veo muy desinteresados de la cuestión. Sin embargo yo he seguido con interés su viaje y puedo decirles que su éxito se basa precisamente en lo sentimental... y eso es lo peligroso».

39. Esta definición aparece ya en los puntos iniciales de la Falange: «Una Nación es una Unidad de Destino en lo Universal. Esa Unidad de Destino se llama España", en FE, $\mathrm{n}^{\circ} 1$ (7 de diciembre de 1933), en recopilación de Río Cisnero, A.: Textos de Doctrina Política de José Antonio Primo de Rivera, Madrid, Almena, 1974, $8^{\text {a }}$ ed., p. 86.

40. A los exiliados se les coloca en la categoría de separatistas a causa de su ignorancia del concepto de Patria falangista, cuestión que podemos deducir de la definición de nación que se hace en los puntos iniciales de Falange: «...habrá que repetirlo siempre, una nación no es una lengua, ni una raza, ni un territorio[...]. El separatismo ignora u olvida la realidad de España [...] se fija(n) en si hablan lengua propia, en si tienen características raciales propias, en si su comarca presenta clima propio o especial fisonomía topográfica», en "Puntos programáticos de Falange Española», FE, no 1 (7 de diciembre de 1933), en Río Cisnero, A.: Op.cit., p. 86. 
España y éste se niegue argumentando que no será bien recibido, a lo que su hermana le responde: "Estás muy engañado Pablo, como casi todos. Fíjate, yo vengo de recorrer toda América y lo sé. Estás equivocado».

Con esas palabras de Victoria, el filme insta a los exiliados a volver a España. Con ello transmite al espectador la imagen de una España alejada de rencores a la que es posible regresar sin que se sufra represión alguna. En este caso, como es usual en la época histórica que estamos analizando, la mención a los exiliados de la Guerra Civil se hace colocándolos en un grupo ideológicamente homogéneo. Sin embargo, no podemos olvidar que la ideología de estos exiliados era plural y que el factor común de esta emigración no solo fue la guerra sino también la aceptación o no del régimen de Franco. El regreso tampoco puede considerarse en un bloque único porque es también conocido que, en unos casos, el retorno es esporádico con la sola intención de reiniciar contacto con otros intelectuales; en el caso de los exiliados hostiles a la España «roja» y desfavorables a la victoria de la "nacional», vuelven a España sin que se produzca ningún acercamiento al gobierno, manteniéndose en lo que se denominaba entonces «tercera España». Una gran mayoría no vuelve ${ }^{41}$.

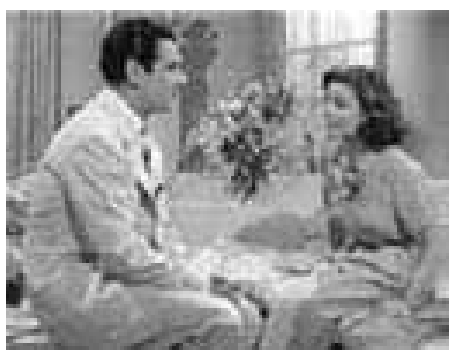

Victoria habla con Pablo

En consonancia con los propósitos propagandísticos y culturales de la época, aparece en el filme una referencia clara a la Hispanidad ${ }^{42}$. Es decir, al conjunto de pueblos hispanos que profesan la misma fe y tienen la misma sangre, porque han sido descubiertos, civilizados y evangelizados por España. La Hispanidad se sugiere en la aparición de un misionero que desea contemplar las actuaciones y en la secuencia en que, sobre la imagen de los bailes, se proyectan figuras de conquistadores a caballo.

Entendemos que, mediante el recurso cinematográfico de sobreimpresión, la película quiere resucitar en estas imágenes los tradicionales vínculos espirituales y raciales entre España y su «hijas americanas» desde el descubrimiento y conquista y destacar que la expedición, considerada también como misión, es otra forma de proseguir aquel hecho histórico porque, con la obra de los Coros y Danzas de la Sección Femenina florecen nuevamente las hazañas de los navegantes conquistadores ${ }^{43}$.

41. LloRens, V.: El exilio español de 1939, Madrid, Taurus, 1976, p. 98.

42. «La Hispanidad no es un mito, sino una realidad histórica; una comunidad en la que viven unos doscientos millones de personas. Nació con el descubrimiento de España y Portugal, pues estos no crearon colonias, sino se prolongaron a sí mismos», Delegación NACional de SeCCión FEMENina: Op. cit., pp. 65 y ss.

43. En la regresión hacia la España Imperial hay una preocupación en el régimen por arbitrar una política cultural hacia Hispanoamérica, en la que cabía resucitar los tradicionales vínculos espirituales y raciales. En esta nueva empresa de carácter universal, España volvería a ocupar el lugar preeminente que le corresponde. Ver Contreras, M.: "Ideología y Cultura» en M. Ramírez, J. A. Portero y otros: Fuentes ideológicas de un régimen (España, 1939-1945), Zaragoza, Pórtico, 1978, pp. 56-80 y 207. 

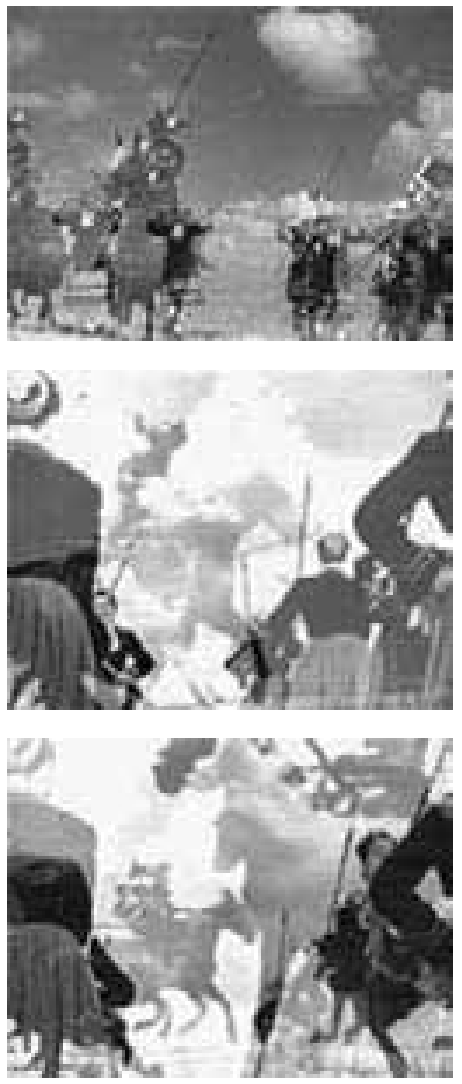

Transparencias de conquistadores a caballo sobre bailarinas

Otro tema destacado es el anticomunismo, que se refleja en la relación de Pablo con unos personajes de habla "no hispana». El filme describe estos personajes como ajenos y malvados; como hombres y mujeres que no sienten preocupación por los demás y cuya actividad está marcada por el egoísmo y la muerte. Esto se percibe claramente en todos los momentos en que aparecen estos personajes. Primero en las palabras de la empleada de Pablo al que advierte de la maldad de estos personajes «mala gente mi amo....", más tarde, en el comportamiento de estos individuos cuando proponen el boicot a las actuaciones y un acto terrorista (paquete bomba en el palco) ${ }^{44}$.

La presencia y acción de estos personajes no sólo sirve para advertir de la conexión de los exiliados con el comunismo y el engaño a que están sujetos, sino también para destacar la figura del exiliado que no tiene deudas pendientes con la justicia. El modelo de todos ellos es Pablo, el hermano de Victoria, al que se define como prototipo de "caballero español» cuyas peculiaridades (religiosidad, sentido de la justicia, defensor de ideales, nobleza, valentía $\mathrm{y}$ arrojo, etc.) perviven aun a pesar de sus errores y equivocaciones.

El miedo, signo de indignidad, de traición y cobardía no tiene cabida en él. Esto se percibe en la secuencia en que defiende a las chicas, enfrentándose con sus amigos o cuando se presenta ante el Capitán para reconocer que ha subido al barco como polizón y, en fin, cuando Ángeles pide a Pablo que vuelva a España y él se

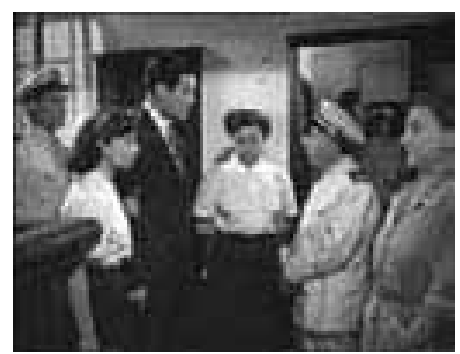

Pablo se entrega al Capitán

44. En el filme se han sintetizado también algunas anécdotas no siempre agradables que se produjeron durante el viaje, como el negarles el servicio en algunos restaurantes, el rechazo de asistencia de algunos tramoyistas, los intentos de reventar el espectáculo con silbidos y pateos y la agresión, sin consecuencias graves, que se produjo en México con un atentado con bomba cuando actuaba el grupo de Santander. Estas anécdotas son comentadas y reconocidas por Primo DE Rivera, Pilar: Op. cit., p. 202. 
niega, sólo el calificativo de cobarde le hace reaccionar ${ }^{45}$.

Es también relevante el protagonismo de los EEUU en el filme, reflejado en la afición de la tripulación y de algunos componentes de la expedición al western (literatura y cine). Esta presencia y la forma en que aparece puede muy bien justificarse por el momento histórico en que, a causa de los cambios que se producen en la situación internacional, se comienza a considerar a Franco no sólo como

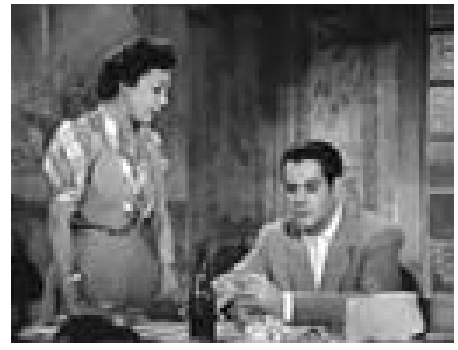

Ángeles recrimina a Pablo su cobardía cabeza del régimen sino también como posible aliado de los EEUU en la lucha para frenar la expansión del comunismo.

Asimismo, el uso de las películas y novelas del oeste se corresponde con la realidad española del momento en la que este género era uno de los predilectos de la narrativa popular ${ }^{46}$. La forma en que se utiliza la referencia a este país define un estereotipo. Como sabemos, el estereotipo forma parte del conocimiento general de la sociedad y, por tanto es referido y aceptado por sus miembros. Además, al ser muy resistente y duradero, pervive en el acervo común y puede ser utilizado como fórmula humorística (chiste típico) o prejuicio.

El mundo del oeste americano introdujo elementos fijos, ingredientes típicos del género (cantante, pianista, barman, cowboy, sheriff, etc.) que formaban parte del «saber» de la sociedad española del momento. El humor que se busca en el filme es fruto de la asociación y de la identificación de esos elementos con otros cotidianos propiamente españoles y supone un guiño de complicidad al espectador. Así, por ejemplo, el sheriff se identifica con las personas de autoridad, sea el Capitán o, incluso el mismo Caudillo; la figura del cowboy, héroe en las películas y novelas en la tarea de establecer sendas y abrir caminos, es equiparable a las componentes de este viaje, héroes/heroinas también de esta cruzada cultural y patriótica. Y, en fin, la trama de la película incluye la acción, el tiroteo y «el salvado en el último momento", moldes clásicos de la novela del oeste.

\section{CONCLUSIONES}

El análisis efectuado hasta ahora del filme Ronda Española nos permite aislar unas cuantas variables que justifican las hipótesis de las que se ha partido y su carácter propagandístico.

En efecto, hemos constatado, una vez más, que en el espacio ficticio del filme se entretejen y reflejan los códigos y mensajes de la sociedad en que esa

45. Piensas que eres un valiente y sólo yo sé que eres un cobarde. Te dio miedo ser un vencido y huiste, ahora te da miedo de hablar con tu hermana [...], miedo de volver a España [...], eres un cobarde».

46. Las novelas del oeste de Marcial Lafuente Estefanía y las de El Coyote de José Mallorquí, tan populares en la época que nos ocupa, tienen un cumplido repaso en el libro colectivo La novela popular en España, Madrid, Robel, 2000. 
obra se produce y que la imagen cinematográfica tiene un significado y un propósito en el contexto de dicha realidad histórica.

Por otra parte, estamos convencidas de que, en el caso de Ronda Española, el carácter propagandístico del filme fue conscientemente buscado desde su concepción y explícitamente declarado y asumido en el relato de ficción, porque hemos podido comprobar que el filme proporciona una serie de temas que son objeto de los eslóganes tradicionales en el discurso ideológico del momento.

De ellos, habría que destacar la concepción jerárquico-autoritaria de la vida mediante la que se define una realidad perfecta y armónicamente vertebrada en la que cada persona tiene su sitio y debe cumplir su misión, lejos de conflictos, disensiones y separatismos que pueden acabar con la armonía; la preocupación continua por la Patria, valor conocido y aceptado a través del que se hace una reinterpretación de la historia de España, destacando su vocación imperial; la unidad nacional, las gestas y hazañas patrióticas de los conquistadores; el catolicismo y su moral, base del experimento histórico unitario de la Religión católica y del Estado nacido de la guerra civil; el reconocimiento de nuestra universalidad cultural (Hispanidad) en la que se integraban las naciones que habían entendido y apoyado mejor a España, unidas a ella por una historia común, fundidas en una sola fe, participantes de una misma idiosincrasia y, en fin, el anticomunismo, referencia condenatoria en la que cabía un amplio espectro de actitudes políticas que poco o nada tenían que ver con esa realidad.

Hemos constatado igualmente que, en esta tarea, la mujer española tiene una misión destacada porque es la misma imagen corporeizada de España ${ }^{47}$. A través de la Sección Femenina, el Estado pide de los ciudadanos no sólo una actitud externa sino también una actitud interna, en base a ese conjunto de valores de los que necesariamente todos deben participar ya que definen y caracterizan el «ser español».

Para concluir, el mensaje, a nuestro entender, tiene una doble finalidad: una orientada al exterior que consiste en acercarse a las naciones hispanoamericanas y a los españoles allí residentes (emigrados y exiliados) y mostrar a la comunidad internacional la imagen de una España que es capaz de valerse por sí misma y que tiene un importante papel en la empresa de "combatir al comunismo»;

47. Es la mujer la que transmite la continuidad de las cosas, su misión es servir. En la empresa de aplastar el comunismo no puede faltar el aliento de la mujer española... Luis Suárez Fernández, al referirse al viaje hacia Hispanoamérica, recoge la crónica que hace Manuel Muñoz Cortés en la que se expresan textualmente estas cuestiones, destacando la eficacia del poder femenino en esta acción: «Personas adversas a nuestra política o lo que es peor, indiferentes y menospreciadoras, se van advirtiendo a sí mismas penetradas y confortadas por ese algo que flota por encima de todo el grupo, por ese misterioso y extraño atractivo femenino, por esa noción española del moverse, del vivir, del pensar y del creer. No saben ellas mismas, no sabe nadie sino el que las ve llegar desde esta lejanía máxima de Chile, la cantidad de España que traen consigo. Después de advertir lo perfecto del espectáculo, de irlas conociendo una a una y sentirse impresionado por la admiración que cada una se gana, se acaba sintetizando casi inadvertidamente todo ello en una idea de rejuvenecimiento de la palabra España... Se siente España más cerca y como más definida y corporeizada...». En SuÁrez Fernández, Luis: Op. cit., p. 222. 
La mujer es el mensaje. Los Coros y Danzas de Sección Femenina en Hispanoamérica

otra hacia adentro, con el propósito de mostrar a los ciudadanos españoles la aceptación y el reconocimiento de la comunidad internacional hacia el régimen y el Caudillo, expresado en las manifestaciones de entusiasmo y cordialidad hacia estas mujeres.

Getafe (Madrid), junio de 2003 